\title{
DESIGN AND DEVELOPMENT OF EMPLOYEE ASSESSMENT APPLICATION PT. TASPEN (PERSERO) WEB-BASED
}

\author{
Muhammad Ayat Hidayat ${ }^{1}$, Saepudin Nirwan ${ }^{2}$ \\ Prodi Pendidikan Teknik Informatika \\ Jurusan Pendidikan Teknik Elektro \\ Universitas Negeri Makassar \\ Imuhammad.ayat.hidayategmail.com \\ 2nirwana73egmail.com
}

\begin{abstract}
All the time the survey procurement process is still rated less efficient because it still uses paper media. The impact, requires a longer cost and time. There are some employees who cheat by doing surveys more than one time. Beside that, HRD (Admin) in this case have difficulty in calculating the survey results in large numbers. Therefore, in final assignment, will be created a manager appraisal application system, thus creating harmonyfor each worker in it which will provide benefits to the institution, company, or hotel.

This application is dedicated to employees. The application system will contain a questionnaire, where the contents of the questionnaire will contain some important things that will serve as guidelines for managers in improving performance based on the input of the employees themselves.
\end{abstract}

Keywords: Manager Performance Appraisal, Questionnaire, Survey

\section{PENDAHULUAN}

\section{$1.1 \quad$ Background}

The current development of the world economy greatly influences the mindset of individuals to work harder in order to get the maximum income. Some people also look for work that can provide benefits beyond their basic income per month. One of the jobs that are currently in demand is Civil Servants (PNS) because according to people's thinking, being a civil servant will get a stable and guaranteed income. ${ }^{[1]}$

Performance or performance is a description of the level of achievement of the implementation of an activity program or policy in realizing the goals, objectives, vision, and mission of the organization as outlined in an organization's strategic planning. Performance can be known and measured if an individual or group of employees have criteria or standards of success that have been determined by the organization. Therefore, if without the goals and targets set in the measurement, then the performance of a person or organizational performance cannot be known if there is no benchmark for success. In a company, human resources are needed which have the quantity and quality of employee work such as neatness, thoroughness, and the interrelatedness of results by not ignoring the volume of work and the volume of work produced in normal circumstances is very influential in a company. ${ }^{[3]}$

Managers are often demanded the efficiency of time and costs, how to arrange for everything to go well. Whether by coming early in the morning, the office continues to sit sweetly on the table is called an exemplary manager and is it enough to benchmark the performance of a manager. Here is the role of a manager, one day he can be a leader and one day he is a servant. Very different role with an employee because he is a worker. A manager, he thinks about the continuity of the institution, maintains the image and responsibility. As a manager, giving the best service to members is a selling point to compete in the era of globalization. A manager does not just sit behind the screen sometimes he also needs spaciousness (Kros checks without the knowledge of employees to find information) so that he can provide input to subordinates about the results of their work in the field and here the manager will receive complaints from members. ${ }^{[3]}$

Problems found in PT. Taspen namely the survey process is still considered to be less than optimal because it still uses paper media. The impact, requires a fee and a longer time. There are several employees who commit fraud by conducting more than 1 time survey. In addition, the HR manager (Admin) in this case has difficulty calculating the results of the survey in large numbers. 
Therefore, it will be built "Appraisal Manager Application System PT. Taspen Web Based "so as to create harmony for every worker in it that will provide benefits to agencies, or companies. The application system will contain a survey in the form of a questionnaire, where the contents of the questionnaire will contain several important things that will be used as guidelines for managers in terms of improving leadership and policies based on the input of the employees themselves.

1. Problem Identification

2. Problem identification is the process of formulating problem problems that will be examined.

3. How to design a manager's rating system?

4. How is the manager's assessment determined?

5. What is the manager's rating system?

\section{2 purpose}

Based on the identification of the problem, the purpose of this study is to find out, examine, and analyze:

1. Knowing the explanation of performance assessment.

2. Knowing the purpose and benefits of performance appraisal.

3. Know about performance assessment criteria.

\subsection{Scope of Problem}

To simplify research and clarify the design of this application without reducing the purpose of the research, then explain it in the scope as follows:

1. The stages of system development are carried out up to the stage of making the program.

2. The programming language used as a system builder is PHP and for database processing is used a MySQL DBMS.

3. The topic of discussion is limited to the employee satisfaction survey process against the manager does not mention the problem of decision support system or decision-making system used by the manager as a determinant of successful performance as a leader.

\section{LANDASAN TEORI}

\section{$2.1 \quad$ Kuesioner}

The questionnaire is an information gathering technique that allows analysts to study the attitudes, beliefs, behaviors, and characteristics of several key people in an organization that can be affected by the proposed system or by an existing system. ${ }^{[2]}$

\subsection{Skala Likert}

The questionnaire is an information gathering technique that allows analysts to study the attitudes, beliefs, behaviors, and characteristics of several key people in an organization that can be affected by the proposed system or by an existing system. [2

\subsubsection{Rumus Skala Likert}

Formulas for obtaining the results of calculating the percentage of diagrams and percentage determination of criteria.

Respondents response:

$\mathrm{T}=$ Total Tanggapan Jawaban

$\mathrm{N}=$ Total Jawaban Responden

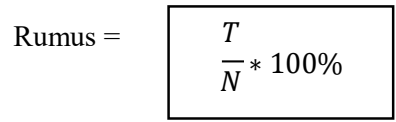

\begin{tabular}{|c|c|}
\hline Alternatif Jawaban & Bobot Nilai Positif (+) \\
\hline Sangat Setuju & 5 \\
\hline Setuju & 4 \\
\hline Netral & 3 \\
\hline Tidak Setuju & 2 \\
\hline Sangat Tidak Setuju & 1 \\
\hline Sumber: Sugiyono (2013:108) &
\end{tabular}

Gambar 2.2.1 Pedoman Pemberian Bobot Pada Nilai Skala Likert

Rumus persentase dari setiap kriteria:

$\mathrm{S}=$ Bobot Nilai Jawaban Skala Likert

$\mathrm{T}=$ Total Tanggapan Jawaban Responden

$$
\begin{aligned}
& \text { Rumus }=\mathrm{S} * \mathrm{~T} \\
& \text { Total }=\left(\mathrm{S}_{1} * \mathrm{~T}\right)+\left(\mathrm{S}_{2} * \mathrm{~T}\right)+\left(\mathrm{S}_{3} * \mathrm{~T}\right)+\left(\mathrm{S}_{4} * \mathrm{~T}\right)+\left(\mathrm{S}_{5} * \mathrm{~T}\right)
\end{aligned}
$$

Rumus Nilai Max:

$\mathrm{S}=$ Bobot Nilai Jawaban Skala Likert

$\mathrm{N}=$ Total Jawaban Responden

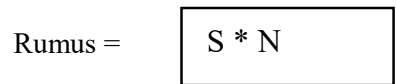

Rumus Hasil Presentase Kriteria:

NT $=$ Total Hasil Perkalian Bobot Jawaban

$\mathrm{M}=$ Hasil Dari Rumus Nilai Max

Rumus $=\frac{\mathrm{NT}}{\mathrm{M}} * 100 \%$

\section{System}

The system is a collection or set of elements or variables that are mutually organized, interact with each other, and are interdependent. Defining the system as a set of elements that are combined with one another for a common purpose. The system consists of elements such as input (input), processing (processing), output (output). According to Henry Prat Fairchild and Eric Kohler the system is an interrelated circuit between several parts of 
the smallest, if a part / sub is interrupted, then the other parts feel the disturbance. ${ }^{[4]}$

\subsection{Survei}

Survei (survey) merupakan sejumlah kuesioner dan wawancara yang bertujuan untuk mengumpulkan informasi dengan secara langsung menanyakan berbagai pengalaman, sikap, atau pendapat. Umumnya, kita cukup terbiasa dengan berbagai jajak pendapat, seperti jajak pendapat Kompas atau A.C. Nielsen. Ada ratusan topik survei, mulai dari prefensi konsumen hingga prefensi seksual. $^{[5]}$

\subsection{Management}

Management is an administrative review in terms of the process. Or management is a process consisting of several activities in an effort to achieve the objectives of cooperation (administration) effectively and efficiently, So it can be concluded that management is a structuring process (utilization) by using potential sources, both human and non-human, in order to achieve goals effective and efficient.

The management function process according to George R. Jerry starts from planning, then continues organizing, actuating, and finally controlling. The process runs cyclic, because once the final process (supervision) has been passed, it will return to the first process (planning) ... ${ }^{[3]}$

\subsection{PT. Taspen}

TASPEN stands for Civil Servant Savings and Insurance Funds. This company was formed in accordance with the Law of the Republic of Indonesia Number 11 of 1969 concerning "Employee Pension and Widow Pension / Employee Width", which further facilitated the Law of the Republic of Indonesia Number 11 of 1992 concerning "Pension Funds", as well as the Republic of Indonesia Law Indonesia Number 40 of 2004 concerning the "National Social Security System" .. ${ }^{[5]}$

\section{$2.7 \quad$ PHP}

The first time PHP was created by Rasmus Lerdorf in 1995 the name was PHP / FI which had an Personal Home Page / Form Interpreter. But in its development, in 1997, Andi Gutmans and Zeev Suraski rewrote PHP which until now was known to be short for the word Hypertext Preprocessor. PHP is classified as open source software which is governed by rules of general purpose licenses (GPL).

PHP programming is very suitable to be developed in a web environment, because PHP is devoted to dynamic web development. That is, PHP is able to produce a website that continuously results can change according to the pattern given. It depends on the client browser request (Opera, Internet Explorer, Mozzila, etc.)

\section{$2.8 \quad$ CSS}

CSS is a document that stands alone and can be included in HTML code or simply a reference by HTML in defining styles. CSS uses structured codes to define styles on HTML elements or can also be used to create new styles commonly called classes. CSS can change the size of the text, change the background color on a page, or can also change the border color on the table, and there are many more things that CSS can do. Inshort, CSS is used to adjust the appearance of HTML. ${ }^{[7]}$

\subsection{Konsep Analisis dan Perancangan \\ 2.9.1 Definisi Analisis}

Analysis comes from Greek (Greek), consisting of the words "ana" and "lysis". Ana means up (above), lysis means to break or destroy. Differentially, "Analysis is a process of resolving data into its constituents to reveal its characteristic elements and structure" [10]. In order for data to be analyzed, the data must be broken down into small parts (according to elements or structures), then combine them together to gain new understanding.

Data analysis is the most vital process in a study. This is based on the argument that in this analysis the data obtained by researchers can be translated into results that are in accordance with scientific principles. Therefore, it needs hard work, creative power and high intellectual ability to get satisfactory results. Data analysis comes from the results of data collection. Because the data that has been collected, if it is not analyzed only becomes an item that is not meaningful, meaningless, becomes dead data, data that does not sound. Therefore, data analysis here serves to give meaning, meaning and value contained in the data. ${ }^{[8]}$

\subsubsection{Flowchart}

Flowchart is a chart that shows the flow (flow) in a program or system procedure logically. While the program flowchart (flowchart program) is a flow chart that is similar to the system flow chart, which is to describe the procedures in the system.

\subsubsection{Flowmap}

Flowmap is a chart that has a flow that describes the steps to solve a problem. Flowmap is a way of presenting an algorithm. There are two types of Flowmap that describe processes with computers, namely:

\subsubsection{Definisi Perancangan}

Design is the design stage (design) has the purpose of designing a new system that can solve the problems faced by an organization that is obtained from the selection of the best alternative systems. ${ }^{[7]}$

\subsubsection{DFD (Data Flow Diagram)}


Data Flow Diagrams are a network that describes an automatic or computerized system, manualization, or a combination of the two, whose drawers are arranged in the form of a collection of system components that are interconnected according to the rules.

\section{$2.10 \quad$ Database}

A database is a set of tables containing data and is a collection of fields or columns. The file structure that composes a database is Data Record and Field.

\subsubsection{MySQL}

MySQL is an open source database server that is quite popular in its existence. With a variety of advantages, this database software is widely used by practitioners to build a project. The existence of API (Application Programming Interface) facilities owned by MySQL, allows various computer applications written in various programming languages to access the MySQL database. Advantages and advantages of using MySQL compared to other databases, including:

1. Many experts think MySQL is the fastest server.

2. MySQL is an OpenSource database management system (the source code is open), which is free or free to use by individuals or agencies without having to buy or pay to the manufacturer.

3. MySQL has a high performance but is simple.

4. MySQL database understands the language of SQL (Structured Query Language).

5. MySQL can be accessed through the ODBC (Open Database Connectivity) protocol made by Microsoft. This causes MySQL to be accessed by many software.

6. All clients can access the server at one time, without having to wait for others to access the database.

7. The MySQL database can be accessed from allplaces on the internet with certain access rights.

8. MySQL can run on a variety of operating systems such as Linux, Windows, Solaris, and others.

\subsection{Pengujian}

Testing is an important part in the development of a software, testing is intended to find errors in the system and ensure that the system built is in accordance with what was planned before. Tests are carried out to ensure quality and also know the weaknesses of the software. The purpose of this test is to ensure that the software that is built has reliable quality, which is capable of presenting a basic study of the specifications of the analysis, design and coding of the software itself

\section{ANALISIS DAN PERANCANGAN}

\subsection{Analisis}

System analysis can be defined as the decomposition of a complete information system into its component parts with a view to identifying and evaluating problems, opportunities, obstacles and expected needs so that improvements can be proposed. In this section, we will discuss the analysis of procedures and current document flow described in the form of flowmap, coding and analysis of non-functional systems which include hardware and software used, and analysis of users involved in the home monitoring system application with whatsapp.

\subsubsection{Analisis Sistem Berjalan (Current System)}

Analysis of the current system, is an early stage analysis in the determination and design of the system. In this analysis there are two methods used, namely: Procedure Analysis (Flowmap) and Analysis of documents used. Thus, the application to be built will actually be in accordance with the procedures and work systems needed.

\subsubsection{Analisis Prosedur Penilaian Pegawai PT. Taspen yang sedang berjalan}

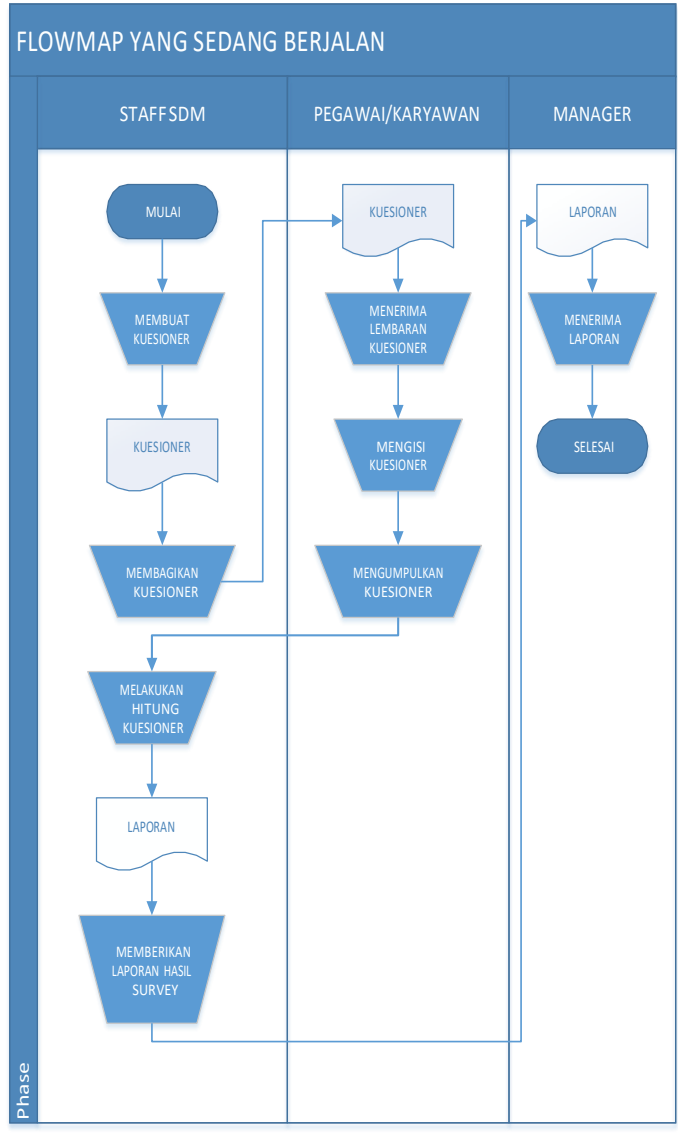

Gambar Error! No text of specified style in document..1 Flowmap yang sedang berjalan

Information :

1. First, HR first makes a questionnaire

2. After that, the questionnaire sheets that have been made are distributed to employees

3. Employees receive questionnaires 
4. Next, employees fill out the questionnaire and are collected again in the HR department

\subsubsection{Analisis Dokumen yang Digunakan}

This analysis is an analysis phase of the documents involved in the application system. The documents used are as follows:

1. Employee Data Documents

Employee Data is data that includes information about employee names, employee emails and other important information related to the employee itself.

2. Data Document on Assessment Result of Manager

Data Result Manager Assessment is data about the results of the survey in PT. The Taspen, which includes the percentage of results from the questionnaire survey.

\subsubsection{Analisis Sistem yang akan Dibangun}

\section{Flowmap Proses Survey yang akan dibangun.}

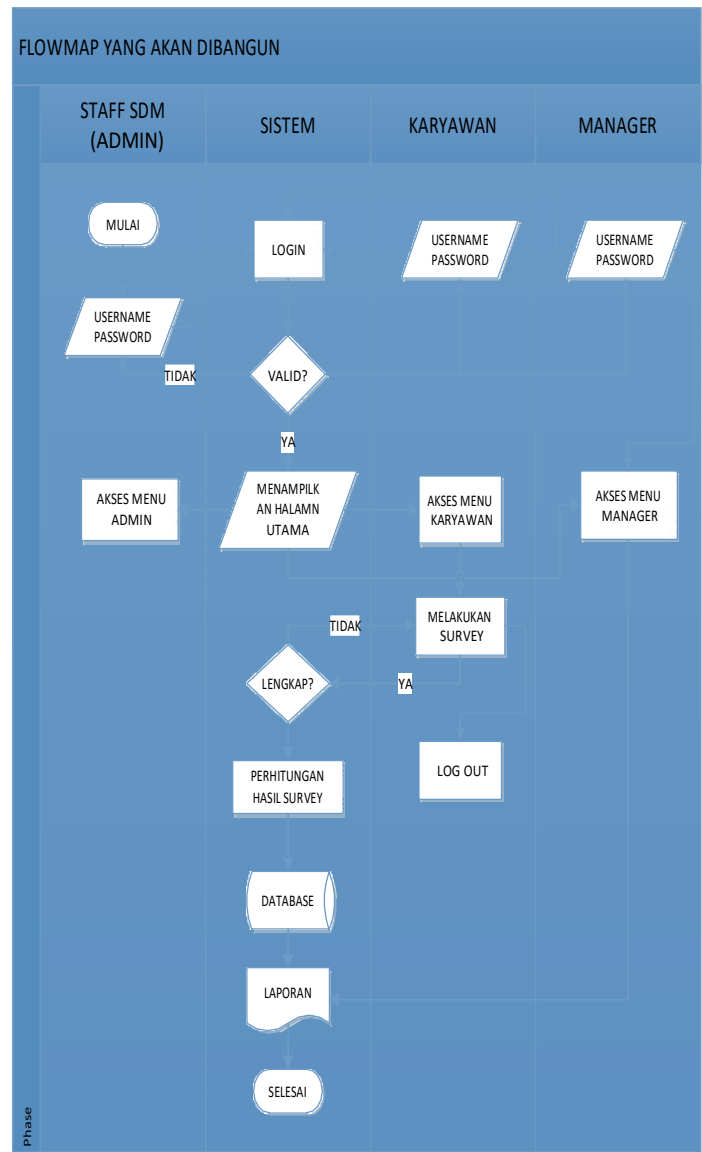

Gambar Error! No text of specified style in document.-2 Flowmap proses survey yang akan dibangun

Information:

1. First, the Admin processes the Login by entering the Username and Password. If the Username and
Password are valid, the System will display the main page. If not, then the employee and manager will return to enter a valid Username and Password.

2. The employee will do the login process by entering the Username and Password. If the Username and Password are valid, it will display the main page and the employee will access the employee menu. If not, then the employee returns to enter a valid Username and Password.

3. Next, employees access the menu and conduct a manager's assessment survey. If the employee has filled out a survey with a complete system, it will $\log$ out automatically because the survey process can only be done once in one employee, then the system will process the results of the survey and will be stored in the database as a report. If not, then the employee must return to complete the survey process.

4. Then the Manager will see the survey results report stored in the system in the form of graph diagrams.

Keterangan:

1. Pertama, Manager masuk ke sistem dengan menginputkan username dan password. Jika input benar maka masuk ke halaman utama. Jika tidak, maka manager akan menginputkan kembali username dan password yang valid.

2. Setelah masuk ke halaman utama, manager melakukan akses menu. Kemudian Manager akan melihat laporan hasil survey yang tersimpan di sistem yang berupa diagram grafik.

\subsubsection{Analisis Perangkat Keras dan Perangkat Lunak}

\section{Analisis Perangkat Keras}

The hardware specifications used are as follows Tabel Error! No text of specified style in document..1 Spesifikasi Perangkat Keras

\begin{tabular}{|l|l|l|l|}
\hline No & $\begin{array}{l}\text { Nama } \\
\text { Perangkat }\end{array}$ & Spesifikasi & Keterangan \\
\hline 1 & Memory & 4 GB RAM & $\begin{array}{l}\text { Memory System } \\
\text { yang digunakan }\end{array}$ \\
\hline 2 & Processor & $\begin{array}{l}\text { Intel } \\
\text { Core }^{\text {TM }} \text { i3 }\end{array}$ & $\begin{array}{l}\text { Untuk kecepatan } \\
\text { transfer data dari } \\
\text { sistem yang } \\
\text { sangat bergantung } \\
\text { pada kecepatan } \\
\text { prosesor } \\
\text { komputer }\end{array}$ \\
\hline 3 & $\begin{array}{l}\text { System } \\
\text { Type }\end{array}$ & $\begin{array}{l}\text { Op4-bit } \\
\text { Operating } \\
\text { System, } \\
\text { x64-Based } \\
\text { Processor }\end{array}$ & \\
\hline
\end{tabular}

\section{Analisis Perangkat Lunak}


Jurnal MediaTIK : Jurnal Media Pendidikan Teknik Informatika dan Komputer

Adapun spesifikasi perangkat lunak (Software) yang digunakan pada aplikasi adalah sebagai berikut:

Tabel Error! No text of specified style in document.2 Spesifikasi Perangkat Lunak

\begin{tabular}{|l|l|l|l|}
\hline No & $\begin{array}{l}\text { Tools / } \\
\text { Software }\end{array}$ & Fungsi & $\begin{array}{l}\text { Keterang } \\
\text { an }\end{array}$ \\
\hline 1. & Windows 10 & $\begin{array}{l}\text { Sistem } \\
\text { Operasi }\end{array}$ & - \\
\hline 2. & MySQL & $\begin{array}{l}\text { Server Basis } \\
\text { Data }\end{array}$ & - \\
\hline 3. & $\begin{array}{l}\text { Google } \\
\text { Chrome }\end{array}$ & Browser & - \\
\hline
\end{tabular}

\subsubsection{Analisis Perhitungan Skala Likert}

At this point will be described the calculation of the Likert scale that is implemented into a system that is adjusted to the availability of data at PT. Taspen. The following is a description of each phase of the Likert scale calculation on the system "Appraisal Manager Manager PT. Taspen KCU Bandung ":

Perhitungan Presentase Diagram

$\begin{array}{ll}\text { Sangat Setuju } & \text { (Total yang menjawab di bagi } \\ & \text { total responden) di kali } 100 \\ & :(6 / 33) * 100 \\ & : 18,2 \% \\ & :(\text { Total yang menjawab di bagi } \\ & \text { total responden) di kali } 100 \\ & :(10 / 33) * 100 \\ \text { Setuju } & : 30,3 \% \\ & :(\text { Total yang menjawab di bagi } \\ & \text { total responden }) \text { di kali } 100 \\ & :(6 / 33) * 100 \\ & : 18,2 \% \\ \text { Netral } & :(\text { Total yang menjawab di bagi } \\ & \text { total responden }) \text { di kali } 100 \\ & :(9 / 33) * 100 \\ & : 27,3 \% \\ \text { Tidak Setuju } & :(\text { Total yang menjawab di bagi } \\ & \text { total responden }) \text { di kali } 100 \\ & :(2 / 33) * 100 \\ & : 6,1 \%\end{array}$

1. Bobot Jawaban Perhitungan Presentase Skala Likert

\begin{tabular}{lr} 
Sangat Setuju & 5 \\
Setuju & 4 \\
Netral & 3 \\
Tidak Setuju & 2 \\
\multicolumn{2}{l}{ Sangat Tidak Setuju : 1}
\end{tabular}

Perhitungan:

Total tanggapan jawaban sangat setuju dikali bobot jawaban sangat setuju

$(6 * 5=30)$
Total tanggapan jawaban sangat setuju dikali bobot jawaban setuju

$(10 * 4=40)$

Total tanggapan jawaban sangat setuju dikali bobot jawaban netral

$(6 * 3=18)$

Total tanggapan jawaban sangat setuju dikali bobot jawaban tidak setuju

$(9 * 2=18)$

Total tanggapan jawaban sangat setuju dikali bobot jawaban sangat tidak setuju

$(2 * 1=2)$

Hasil Total : $40+18+18+2=108$

\section{Menetukan Hasil Maximal}

Bobot jawaban tertinggi dikali jumlah responden $(5 * 33=165)$

3. Menentukan Hasil Presentase Kriteria

(Hasil total dibagi nilai maximal) dikali 100

$108 / 165 * 100$

$=65,4 \%$

\subsection{Perancangan \\ 3.2.1 Context Diagram}

Context diagram adalah sebuah diagram sederhana yang menggambarkan hubungan antara entity luar, masukan dan keluaran dari sistem. Context Diagram direpsentasikan dengan lingkaran tunggal yang mewakili keseluruhan sistem. ${ }^{[9]}$

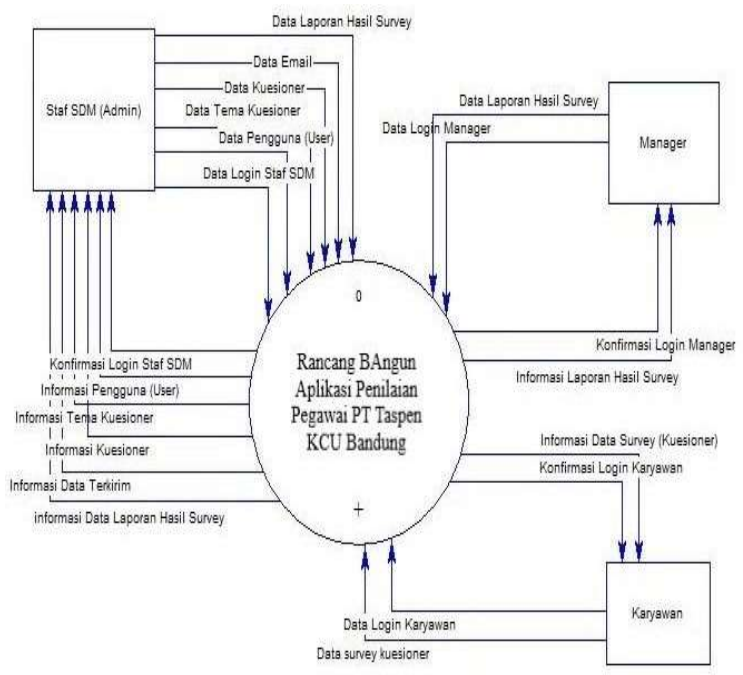


Gambar Error! No text of specified style in document..3 Data in, context diagram Rancang Bangun Aplikasi Penilaian Pegawai PT Taspen KCU Bandung Berbasis WEB

Tabel Error! No text of specified style in document.-3 context diagram Rancang Bangun Aplikasi Penilaian Pegawai PT Taspen KCU Bandung Berbasis WEB

\begin{tabular}{|l|l|l|}
\hline Proses & Data in & Data out \\
\hline \multirow{4}{*}{$\begin{array}{l}\text { Aplikasi } \\
\text { Penilaian }\end{array}$} & Login & $\begin{array}{l}\text { Konfirmasi } \\
\text { Data Login }\end{array}$ \\
\cline { 2 - 3 } $\begin{array}{l}\text { Manager } \\
\text { Berbasis } \\
\text { Web }\end{array}$ & Data & $\begin{array}{l}\text { Informasi } \\
\text { Karyawan }\end{array}$ \\
\cline { 2 - 3 } & Kata Tema & Informasi Data \\
& Kuesioner & Kuesioner \\
\cline { 2 - 3 } & Data Laporan & $\begin{array}{l}\text { Informasi Tema } \\
\text { Laporan Hasil } \\
\end{array}$ \\
\cline { 2 - 3 } & Hasil Survey & Survey \\
\hline
\end{tabular}

\subsubsection{Struktur Menu}

Fungsi-fungsi yang dirancang pada tahap perancangan ini, dibagi kedalam beberapa menu yang bertujuan untuk memudahkan pengoprasian program. Menu yang digunakan pada program saait ini dapat program saat ini dapat dilihat pada struktur berikut:

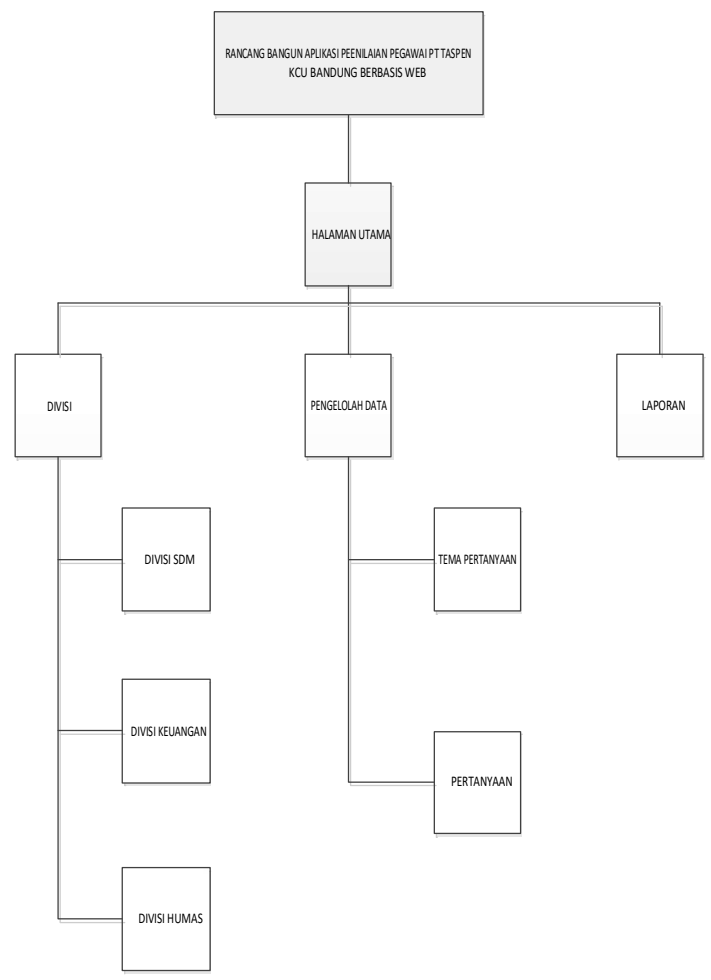

Gambar Error! No text of specified style in document..4 Arsitektur struktur halaman situs
4.1 Implementasi

4.1.1 Lingkungan Implementasi

Implementation is an application or function of an application that is made to be used in a process that has been previously designed.

\subsubsection{Perangkat Lunak (Software) yang} Digunakan

The software used to access this web application is:

1. Operating System: Microsof Windows 10 Enterprise 64-bit

2. Database: MySQL 5.6

Apache 2.14.7

3. Programming: PHP

\subsubsection{Perangkat Keras (Hardware) yang} Digunakan

Perangkat keras yang digunakan untuk akses aplikasi web ini adalah:
a. Processor : Intel ${ }^{\circledR}$ core $^{\mathrm{TM}} \mathrm{i}_{3}$
b. Memori :4 GB RAM
c. Harddisk : $500 \mathrm{~GB}$
d. Monitor : 14 inch

\subsubsection{Tampilan Antar Muka}

4.1.3 Based on the design that has been made for the interface, the results obtained from the implementation consist of several page snippets, including:

1. Halaman Utama

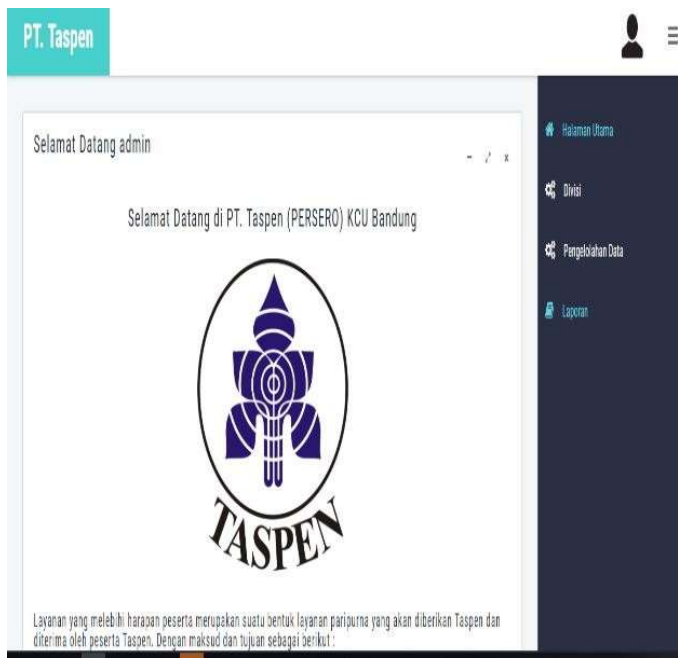

Gambar 4.1 Halaman Utama Admin

2. Halaman Divisi

\section{IMPLEMENTASI DAN PENGUJIAN}




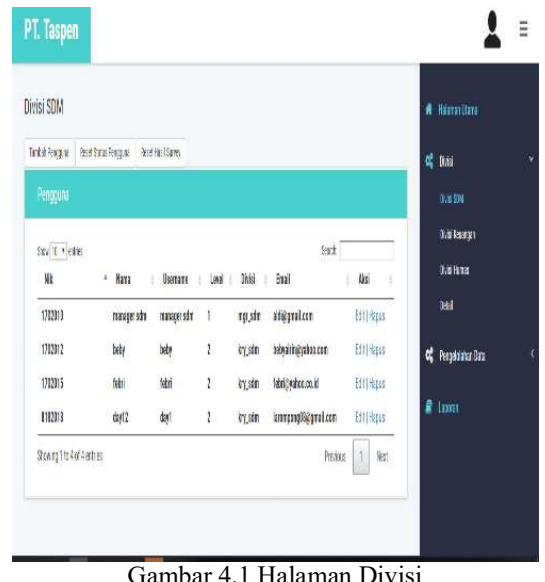

Gambar 4.1 Halaman Divisi

3. Halaman Pengelolahan Data

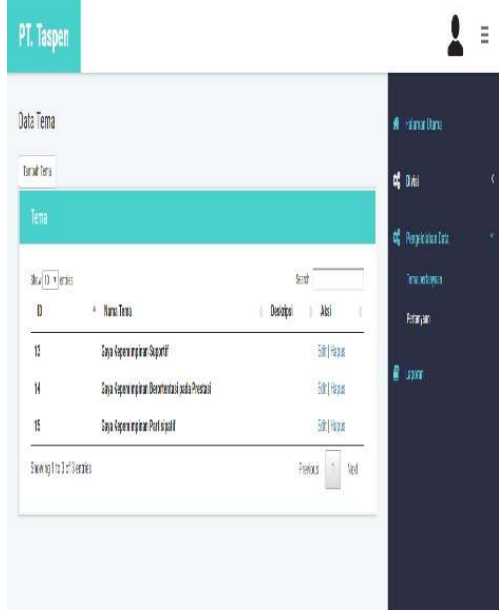

Gambar Error! No text of specified style in document..5 Halaman Pengelolaan Data Tema Pertanyaan

4. Halaman Karyawan

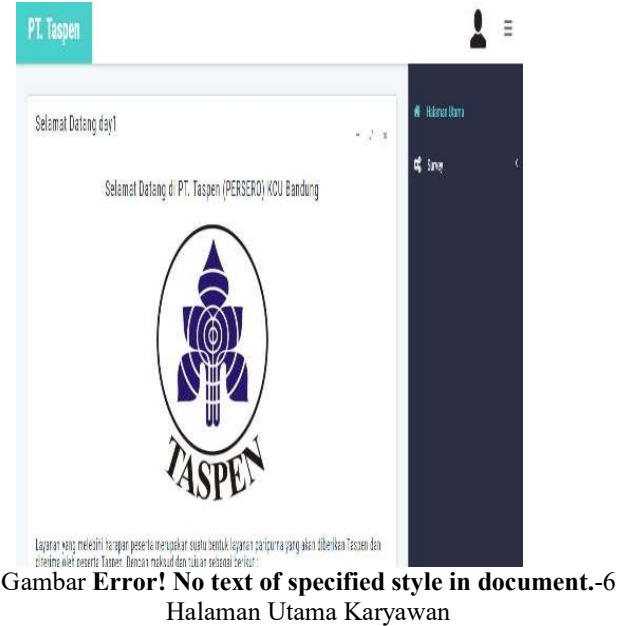

5. Halaman Utama Manager

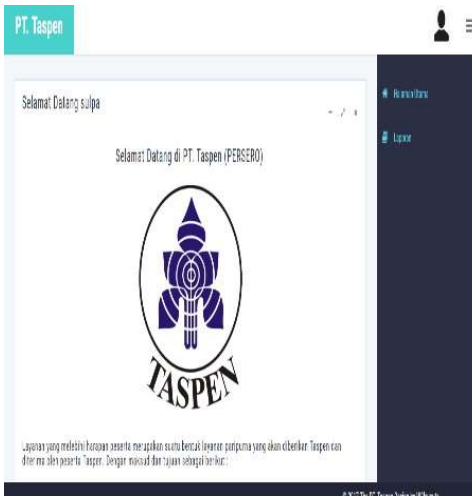

Gambar Error! No text of specified style in document..7 Halaman Utama Manager

6. Halaman Laporan
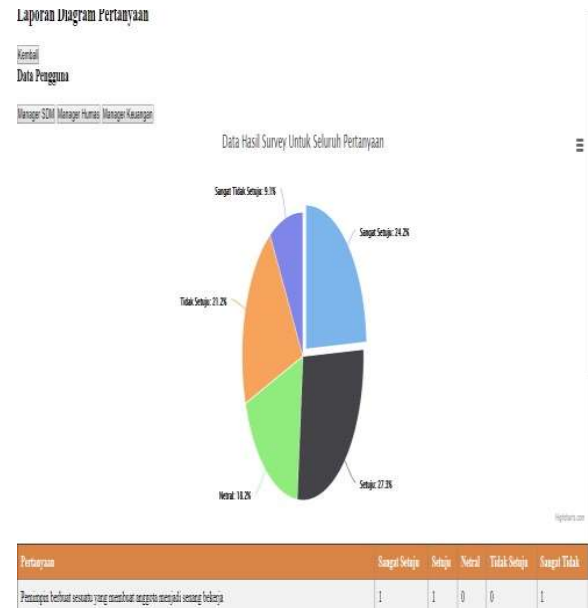

Gambar Error! No text of specified style in document.-8 Halaman Laporan Diagram Keuangan

\section{KESIMPULAN DAN SARAN}

\subsection{Kesimpulan}

The conclusions that can be drawn from the Design of Employee Appraisal Application of PT. Webbased Taspen is as follows:

1. The Design of the Employee Appraisal Application has been completed, this is evidenced by the application that has been able to make an assessment.

2. Produce applications that can facilitate the survey process

3. Produce an application that can facilitate the admin to do the survey calculation process

4. Produce applications to reduce cheating of employees who conduct more than 1 time survey 
Jurnal MediaTIK : Jurnal Media Pendidikan Teknik Informatika dan Komputer

\subsection{Saran}

From the above conclusions, there are some suggestions that are expected to help and overcome the shortcomings of this application, namely:

1. Further research may add functions or other features that can facilitate the use of applications.

2. We recommend that the manager's valuation method be maintained to give satisfaction to all parties, both to the manager, employees and to the company.

\section{DAFTAR PUSTAKA}

[1] WikiPNS, Apa Pengertian PNS, Oktober 24, 2016 http://wikipns.com/apa-pengertian-pns/

[2] Diedit.com, Pengertian Skla Likert dan Cara Hitung Kuesionernya, April 22, 2018, https://www.diedit.com/skala-likert/

[3] Zaulkarnain Wildan, Raden Bambang Sumarsono. "Manajemen Perkantoran Profesional".Penerbit Gunung Samudera. Malang: 2015

[4] Hedi Sasrawan, 36 Pengertian Sistem Menurut Para Ahli, Januari 25, 2014, http://hedisasrawan.blogspot.com/2014/01/25pengertian-sistem-menurut-para-ahli.html

[5] Profile PT taspen kcu bandung 26 Maret 2018 19:00 WIB [Online] http://www.taspen.id

[6] Wade, Carol. "Psikologi". Jilid 1. Halaman 49. Penerbit Erlangga. Jakarta: 2013

[7] R'TECH \& GAME, Pengertian HTML, CSS, PHP, MySQL, Juni 28, 2016, http://blog.unnes.ac.id/rachmatullah/2016/06/28/peng ertian-html-css-php-mysq1/

[8] Cocoreturn, Pengertian Analisis dan Perancangan, April 19, 2013

http://cocoreturn.blogspot.com/2013/04/analisaperancangan-sistem-2.html

[9] Gozali, Lukman, Erwin Gunadhi, and Rina Kurniawati. "Perancangan Sistem Informasi Penjualan Buku Pada PD. Restu Percetakan." Jurnal Algoritma 9.01 (2013). 